\title{
IAMJ
}

INTERNATIONAL AYURVEDIC MEDICAL JOURNAL

do) $\bigcirc \bigcirc$

\section{Tulsi (Ocimum Sanctum Linn.): AN AYURVEDIC AND CONTEMPORARY REVIEW}

\author{
Preeti $^{1}$, A Ramamurthy ${ }^{2}$, Krutika Chaudhary ${ }^{3}$ \\ ${ }^{1,2,3}$ National Institute of Ayurveda, Jorawar Singh Gate, Amer Road, Jaipur, Rajasthan 302002
}

Corresponding Author: Preetinanda15401@gmail.com

\section{https://doi.org/10.46607/iamj3409122021}

(Published Online: December 2021)

Open Access

(C) International Ayurvedic Medical Journal, India

Article Received: 25/11//2021 - Peer Reviewed: 03/12/2021 - Accepted for Publication 06/12/2021

\section{Check for updates}

\begin{abstract}
Tulsi (Ocimum sanctum Linn. Family - Lamiaceae) has been revered in India for over five thousand years, as a healing balm for body, mind and spirit, and is known to bestow an amazing number of health benefits. It is a medicinal herb used in the indigenous system of medicine. Tulsi has been adored in almost all ancient ayurvedic texts for its extraordinary medicinal properties. It is pungent -bitter(tikta) in taste and hot (Ushna), light(laghu) and dry $(r u k s a)$ in effect. Its seeds are considered to be cold in effect. The roots, leaves and seeds of Tulsi possess several medicinal properties. Ayurvedic texts categorise Tulsi as a stimulant, aromatic and antipyretic. In the present review, the reported scientific activity of Tulsi is compiled and collected from different compendia and available literature presented systematically. In the present review, the references related to Tulsi are collected and compiled from different Ayurvedic texts, Modern research articles and other relevant compendia. This review is presented in a systematic manner which will help the researchers as well as clinicians dealing with Tulsi to know its proper usage as this herb is seemed to be highly valuable, possessing many pharmacological/medicinal properties according to Ayurveda as well as modern aspects.
\end{abstract}

Keywords: Ayurveda, Drug Research, Holy basil, Immunity, Tulsi

\section{INTRODUCTION}

Tulsi is one of the aromatic plants, distributed mainly in the tropical and subtropical regions of the world including India. Tulsi - The Queen of Herbs is the most sacred herb which is cultivated and worshipped 
in every house of India. It is an erect, muchbranched, fragrant and sericeous plant attaining a height of about 30-60 $\mathrm{cm}$ when mature. Its aromatic leaves are simple, opposite, elliptic, oblong, obtuse or acute with entire or substrate or dentate margins, growing up to $5 \mathrm{~cm}$ long. The Tulsi flowers are small, purplish in elongate racemes in close whorls. The fruits are small, and the seeds are reddish yellow with mucilaginous texture in consumption. The plant is distributed, cultivated and worshipped in temples and houses of Hindus. This is commonly known as Vishnu-Priya, which means the one that pleases Lord Vishnu.

The genus Ocimum comprises more than 150 species and is considered as one of the largest genera of the Lamiaceae family (Evans, 1996),-Tulsi is described as sacred (Anonymous, 1991) and medicinal plant in ancient literature (Kirtikar and Basu, 1975). The name Tulsi is derived from 'Sanskrit', which means "Matchless One" (Ghosh, 1995). Among the plants known for medicinal value, the plants of genus Ocimum are very important for their therapeutic potentials. Ocimum sanctum Linn. (Tulsi), Ocimum gratissium Linn. (Ram Tulsi), Ocimum canum Linn. (DulalTulsi), Ocimum basilicum Linn. (Ban Tulsi), Ocimum kilimandscharicum Linn. Ocimum ammericanum Linn. Ocimum camphora Linn. and Ocimum micranthum Linn. are examples of known important species of genus Ocimum which grow in different parts of the world and are known to have medicinal properties (Atal,1989, Sen1993; Nagarajun,1989). Tulsi is commonly cultivated in gardens. Two types of Ocimum sanctum $L$. are frequently found in cultivation: (i) Tulsi plants with green leaves known as Sri Tulsi \& (ii) Tulsi plants with purple leaves known as Krishna Tulsi (Bauer, 1997)

\subsection{Properties and Action}

Rasa: Katu, Tikta, Kashaya

Guna: Laghu, Ruksa, Tikshna

Virya: Ushna

Vipaka: Katu

Karma: Dahakarta, Vranashodhaka, Hardya, Karmighna, Kaphahara, Pittahara

\subsection{Phytoconstituents}

Some of the main chemical constituents of tulsi are oleanolic acid, ursolic acid, rosmarinic acid, eugenol, carvacrol, linalool, $\beta$-caryophyllene (about 8\%), $\beta$ elemene (c.11.0\%), and germacrene D (about 2\%). However, the best known of many active components that have been identified and extracted are eugenol (an essential oil) and ursolic acid (Miller 2013)

Fresh leaves and stem of Ocimum sanctum extract yielded some phenolic compounds (antioxidants) such as cirsilineol, circimaritin, isothymusin, apigenin and rosameric acid, and appreciable quantities of eugenol. (Yanpallewar,2004)

Two flavonoids: viz., orientin and vicenin from aqueous leaf extract of OS have been isolated (Gupta,2002). Ursolic acid, apigenin, luteolin, apigenin-7O-glucuronide, luteolin-7-O glucuronide, orientin and molludistin have also been isolated from the leaf extract (Nair,1982). OS also contains a number of sesquiterpenes and monoterpenes viz., bornyl acetate, $\beta$-element, neral, $\alpha$-and $\beta$-pinenes, camphene, campesterol, cholesterol, stigmasterol and $\beta$-sitosterol (IDMA. 2002).

\subsection{Toxicity Study}

The median lethal dose $\left(\mathrm{LD}_{50}\right)$ of OS fixed oil was determined after intraperitoneal administration in mice. The fixed oil was well tolerated up to $30 \mathrm{ml} / \mathrm{kg}$, while $100 \%$ mortality was recorded with a dose of 55 $\mathrm{ml} / \mathrm{kg}$. The $\mathrm{LD}_{50}$ of oil was $42.5 \mathrm{ml} / \mathrm{kg}$. There was found no untoward effect on subacute toxicity study of OS fixed oil at a dose of $3 \mathrm{ml} / \mathrm{kg} /$ day, IP for 14 days in rats (Singh,2007).

\section{Material and methods}

\subsection{Pharmacological Action}

Tulsi is ranked among the few wonders plant for having enormous medicinal potentialities which act as a panacea for a number of ailments and diseases. Each and every part of the plant is useful in various dosages for ample ailments. Ample of pharmacological investigations have been carried out in $O$. sanctum during the recent past and the studies suggest that the plant possesses vital biological activity against a number of ailments and diseases. 
On the basis of various experimental and clinical research, the following pharmacological activities or medicinal properties of OS have been reported.

2.2.1. Antistress activity: The plant Ocimum sanctum has been found to possess adaptogenic properties when tested against a battery of experiments in mice and rats (Bhargava1981, Dadkar 1988, Sen1992, Tabassum,2010). Basil leaves to increase the capacity to cope, against stress (adaptogenic). Even a healthy person can chew 12 leaves of basil, twice a day to prevent stress. (Cohen 2014)

2.2.2. Antibiotic property: Ocimum sanctum also possesses antifungal activity against Asperigillusniger and aqueous extract of it was found to be effective in patients suffering from viral encephalitis (Rajeshwari 1992). Tulsi leaves paste is indeed found to be very effective. Tulsi has significant natural antibacterial, antiviral and antifungal activities and is helpful in treating many serious systemic diseases, as well as localized infections. Ocimum sanctum fixed oil showed good antibacterial activity against Bacillus pumilus, Pseudomonas aeruginosa and S. aureus. Higher content of linolenic acid in OS fixed oil could contribute towards its antibacterial activity (Singh 2005).

2.2.3. Antipyretic activity: The antipyretic activity of Ocimum sanctum fixed oil was evaluated by testing it against typhoid-paratyphoid A/B vaccineinduced pyrexia in rats. The oil on IP administration considerably reduced the febrile response indicating its antipyretic activity. At a dose of $3 \mathrm{ml} / \mathrm{kg}$, the antipyretic activity of the oil was comparable to aspirin. Further, the fixed oil possessed prostaglandin inhibitory activity and the same could explain its antipyretic activity (Singh,2005).

2.2.4. Hepatoprotective activity: Oral administration of hydroethanolic extract of Ocimum sanctum leaves@200 mg/kg in male Wistar albino rats gave protection against liver injury induced by paracetamol (Chattopadhyay, 1992).

2.2.5. Antidiabetic activity: The ethanolic extract of Tulsi leaves leads to marked lowering of blood sugar in normal glucose fed hyperglycaemic \&streptozocin induced diabetic rats (Skaltsa, 1987).
2.2.6. Antioxidant activity: Antioxidant activity of the flavonoids (orientin and vicenin) in vivo was expressed in a significant reduction in the radiationinduced lipid peroxidation in mouse liver (Uma Devi,2000). The aqueous extract also decreased LPO formation (thiobarbituric acid reactive substances TBARS) and increased antioxidant enzymes like superoxide dismutase (SOD), catalase (CAT), glutathione peroxidase (GPX), glutathione transferases (GT). It also increased antioxidant like reduced glutathione (GSH) levels in plasma and liver, lung, kidney and brain of rats (Hussain,2001).

2.2.7. Antimalarial activity: Ayurvedic preparation containing Ocimum sanctum, Piper nigram Linn. and Curcuma longa Linn. has been shown to possess antimalarial activity against Plasmodium vivax and highly effective against Plasmodium falciparum (Rajeshwari,1992). A decoction prepared from the roots of the Tulsi plant is used as a diaphoretic in malarial fever (Pandey,1990). Tulsi is an important constituent of many Ayurvedic cough syrups and expectorants.

2.2.8. Antiulcer activity: The fixed oil of Ocimum sanctum administered intraperitoneally elicited significant antiulcer activity against aspirin, indomethacin, alcohol (ethanol 50\%), histamine, reserpine, serotonin or stress-induced ulcers in rats (Singh, 2007).

2.2.9. Anti-inflammatory activity: Methanolic extract $(500 \mathrm{mg} / \mathrm{kg})$ and an aqueous suspension of $\mathrm{Oci}$ mum sanctum showed analgesic, antipyretic and antiinflammatory effects in acute (carrageenan-induced pedal oedema) and chronic (croton oil-induced granuloma and exudate formation) inflammations in rats (Godhwani, 1987), (Kalabharathi 2011)

2.2.10. Analgesic activity: The Ocimum sanctum oil was found to be devoid of analgesic activity in experimental pain models (tail-flick, tail clip and tail immersion methods). However, it was effective against the acetic acid-induced writhing method in mice in a dose-dependent manner. The writhing inhibiting activity of the oil is suggested to be peripherally mediated due to the combined inhibitory effects of prostaglandins, histamine and acetylcholine (Singh, 1995). 


\section{RESULTS AND DISCUSSION}

The inclusion of Tulsi in Indian culture and the religious practice itself is suggestive of its importance. In Ayurveda classics, the drug is reported with $v a$ takaphahara and Pittakaraka property. It is reported having Shwasahara, Krimighna, Vishaghna, Kasaghna, Jwarghna, Putigandhanashan, Vranashodhan, Deepana, Rochanakarma and indicated in Shwasa, Krimi, Kasa, Vrana, Jawara, Kandu, Swarya by samhita and lexicons of Ayurveda. (Table 1). It is also observed having antipyretic, antidiabetic, antioxidant, antibiotic, anti-inflammatory, hepatoprotective activity and anti-stress activity in various experimental models. The drug is reported for indications like indigestion, cough, urticaria, malarial fever, greying of hairs, wound-and earache (Table2). Hence, we can use this drug in clinical practice to cure various ailments.

Table 1. Karma of Tulsi reported in Brihadtrayee

\begin{tabular}{|c|c|c|c|c|c|}
\hline Sl. No. & Karma & Charaka & Sushruta & AstangaHaridya & AstangaSanghara \\
\hline 1. & Shwasahara & $\checkmark$ & $\checkmark$ & $\checkmark$ & $\checkmark$ \\
\hline 2. & Krimighna & $\checkmark$ & $\checkmark$ & $\checkmark$ & $\checkmark$ \\
\hline 3. & Vishaghna & $\checkmark$ & $\checkmark$ & $\checkmark$ & $\checkmark$ \\
\hline 4. & Kasaghna & $\checkmark$ & $\checkmark$ & $\checkmark$ & $\checkmark$ \\
\hline 5. & Kandughna & $\checkmark$ & - & $\checkmark$ & $\checkmark$ \\
\hline 6. & Jwarghna & $\checkmark$ & $\checkmark$ & $\checkmark$ & $\checkmark$ \\
\hline 7. & Putigandhanashan & $\checkmark$ & $\checkmark$ & $\checkmark$ & $\checkmark$ \\
\hline 8. & Kaphvaatghna & $\checkmark$ & $\checkmark$ & - & $\checkmark$ \\
\hline 9. & Kaphaghna & - & $\checkmark$ & - & $\checkmark$ \\
\hline 10. & Pittakarak & $\checkmark$ & $\checkmark$ & - & - \\
\hline 11. & Kusthaghna & $\checkmark$ & $\checkmark$ & $\checkmark$ & - \\
\hline 12. & Vranashodhan & - & $\checkmark$ & $\checkmark$ & $\checkmark$ \\
\hline 13. & Swarya & $\checkmark$ & - & - & $\checkmark$ \\
\hline 14. & Shirovirechan & $\checkmark$ & $\checkmark$ & $\checkmark$ & $\checkmark$ \\
\hline 15. & Shoolaghna & - & $\checkmark$ & - & - \\
\hline 16. & Deepana & - & - & $\checkmark$ & - \\
\hline 17. & Rochana & - & - & $\checkmark$ & - \\
\hline 18. & Vidahi & - & - & $\checkmark$ & $\checkmark$ \\
\hline 19. & Haridya & - & - & $\checkmark$ & - \\
\hline 20. & Sheetaghna & - & - & - & $\checkmark$ \\
\hline
\end{tabular}

Table 2. Uses and Indications of Tulsi

\begin{tabular}{|l|l|l|l|l|}
\hline $\begin{array}{l}\text { Sl. } \\
\text { No. }\end{array}$ & Indication/Diseases & $\begin{array}{l}\text { Part of Tulsi used } \\
\text { for preparation }\end{array}$ & Plants used in the preparation & $\begin{array}{l}\text { Reported activities in experi- } \\
\text { mental models }\end{array}$ \\
\hline 1. & Indigestion & Leaves & $\begin{array}{l}\text { Tulsi (Ocimum Sanctum Linn.) } \\
\text { \&Sunthi (ZingiberofficinaleRoxb.) }\end{array}$ & $\begin{array}{l}\text { Hepatoprotective activity (Chat- } \\
\text { topadhyay,1992). }\end{array}$ \\
\hline 2. & Cough & Leaves & Tulsi juice (Ocimum Sanctum Linn.) & $\begin{array}{l}\text { Antibiotic property } \\
\text { (Rajeshwari 1992). }\end{array}$ \\
\hline 3. & Makkalla & Leaves & $\begin{array}{l}\text { Tulsi juice (Ocimum Sanctum Linn.) } \\
\text { \&Old Jaggery }\end{array}$ & $\begin{array}{l}\text { Analgesic activity, (Singh1992) } \\
\text { Anti-inflammatory activity (God- } \\
\text { hwani,1987). }\end{array}$ \\
\hline 4. & Urticaria & Leaves & $\begin{array}{l}\text { Tulsi (Ocimum Sanctum Linn.) juice } \\
\text { L/A }\end{array}$ & $\begin{array}{l}\text { Anti-inflammatory activity (God- } \\
\text { hwani,1987). }\end{array}$ \\
\hline 5. & Malarial fever & Root & Tulsi (Ocimum Sanctum Linn.) \& & Antimalarial activity \\
\hline
\end{tabular}




\begin{tabular}{|l|l|l|l|l|}
\hline & & $\begin{array}{l}\text { Dronapuspi juice (Leucas cephalo- } \\
\text { tesspreng.) }\end{array}$ & (Pandey,1990). \\
\hline 6. & Graying of Hair & Leaves & $\begin{array}{l}\text { Tulsi juice (Ocimum Sanctum Linn.) } \\
\text { \& Coconut Oil (Cocos nucifera } \\
\text { Linn.) }\end{array}$ & $\begin{array}{l}\text { Antioxidant activity } \\
\text { (Hussain,2001). }\end{array}$ \\
\hline 7. & Wound & Leaves & $\begin{array}{l}\text { Tulsi juice (Ocimum Sanctum Linn.) } \\
\text { \&Haridra powder (Curcuma longa } \\
\text { Linn.) }\end{array}$ & $\begin{array}{l}\text { Antiulcer activity, (Singh, 2007). } \\
\text { Analgesic activity, (Singh1992) } \\
\text { Anti-inflammatory activity (God- } \\
\text { hwani,1987). }\end{array}$ \\
\hline 8. & Earache & Leaves & Tulsi juice (Ocimum Sanctum Linn.) & $\begin{array}{l}\text { Analgesic activity, (Singh1992) } \\
\text { Anti-inflammatory activity (God- } \\
\text { hwani,1987). }\end{array}$ \\
\hline
\end{tabular}

\section{CONCLUSION}

Tulsi is a common herb grown in many households with a wide range of therapeutic properties. Tulsi is considered being an adaptogen, balancing different processes in the body, and helpful for adjusting to physical and mental stress. The drug may be explored for its immunological actions, rejuvenating, antidiabetic, actions according to Ayurveda. It is easily available non-controversial, multipurpose Ayurvedic medicine.

\section{Acknowledgements}

We are thankful to the vice-chancellor, Prof. Sanjeev Sharma, Pro vice-chancellor \& HOD (Dravyaguna Department) Prof. Mita Kotecha, Registrar \& my guide Prof. A. Ramamurthy, National Institute of Ayurveda, Jaipur, Rajasthan for providing necessary facilities and encouragement.

\section{REFERENCES}

1. Anonymous 1991. Wealth of India. Vol.7. Publication and Information Directorate, CSIR, New Delhi;.79-89.

2. Atal C.K, Kapoor B.M. 1989 Cultivation and utilization of medicinal plants (Eds. PID CSIR).

3. Bauer K, Garbe D, Surburg H 1997 Common fragrance and flavor materials. 3rd edition, Weinheim: Wiley-VCH; 171

4. Bhargava KP, Singh N. 1981 Antistress activity of Ocimum sanctum linn. Indian J Med Res. 73: 443451.

5. Chattopadhyay RR, Sarkar SK, Ganguly S, Medda C, Basu TK.,1992 Hepatoprotective activity of $O$. sanc- tum leaf extract against paracetamol induced hepatic damage in rats. Indian J Pharmacol. 24: 163.

6. Cohen, M. M. (2014). Tulsi - Ocimum sanctum: A herb for all reasons. Journal of Ayurveda and Integrative Medicine, 5(4), 251. https://doi.org/10.4103/09759476.146554

7. Dadkar VN, Joshi AG, Jaguste VS, Billimoria FR, Dhar HL1988 Antistress activity of Ocimum sanctum (Tulsi). Indian Drugs; 25(5): 172-175.

8. Evans W.C. Trease and Evans 1996 Pharmacognosy W.B. Saunders Company London; 48.

9. Ghosh G.R. 1995New Approaches to Medicine and Health (NAMAH) (3). 23-29.

10. Godhwani S, Godhwani JL, Vyas DS 1987, Ocimum sanctum: an experimental study evaluating its antiinflammatory, analgesic and antipyretic activity in animals. J Ethnopharmacol 21(2): 153-163.

11. Gupta SK, Prakash J, Srivastava S 2002 Validation of traditional claim of Tulsi, Ocimum sanctum Linn. as a medicinal plant. Indian J Exp Biol 40:765-773.

12. Hussain EHMA, Jamil K and Rao M. 2001 Hypoglycemic, hypolipidemic and antioxidant properties of Tulsi (Ocimum sanctum) on streptozotocin induced diabetes in rats. Indian J of Clin Biochemistry, 16(2): 190-194

13. IDMA. 2002 Indian Herbal Pharmacopoeia. Mumbai, India: p. 272

14. Kalabharathi H. 2011 Anti-inflammatory activity of fresh tulsi leaves in albino rats, citeseer 5(4)

15. Kirtikar K.R, Basu B.D 1975. Indian Medicinal Plant. 2nd Ed. Vol. 3, New Connaught Place, Dehradun

16. Miller R and Miller S. Tulsi green and Herbs. India's Holy Basil. htpp://www.omorganic.com/tulsi 23J03:16 
17. Nagarajun S, Jain H.C, Aulakh G.S 1989 Indigenous plants used in the control of Diabetes. In: Cultivation and utilization of medicinal plants. Editors: Atal C.K and Kapoor B.M (Published by PID CSIR) 584.

18. Nair AGR, Gunasegaran R, Joshi BS. 1982, Chemical investigation of certain south Indian plants. Indian J Chem 21B: 979.

19. Pandey BP, Anita. In 1990: Economic Botany (Published by Chand and Company Ltd., Ramnagar, New Delhi), p. 294

20. Pandey G., Madhuri S. 2010 Pharmalogicalactivites of ocimumsanctum (Tulsi): A Review 5(1):61-66

21. S. Rajeshwari 19920cimum sanctum. The Indian home remedy. In: Current Medical Scene, (Edited and published by, Cipla Ltd., Bombay Central, Bombay

22. S. Rajeshwari,1992 Ocimum sanctum. The Indian home remedy. In: Current Medical Scene, (Edited and published by Cipla Ltd., Bombay Central, Bombay).

23. Sen P, Maiti PC, Puri S, Ray A, Audulov NA and Valdman AV. 1992 Mechanism of anti-stress activity of Ocimum sanctum Linn Eugenol and Tinosporamalabarica in experimental animals. Indian J Exp Biol. 30 (7): 592-596.

24. Sen P. 1993 Therapeutic potentials of Tulsi: from experience to facts. Drugs News \& Views 1(2).15-21.

25. Singh S, Majumdar DK 1995 Analgesic activity of Ocimum sanctum and its possible mechanism of action. Int J Pharmacogonosy 33,188.
26. Singh S, Malhotra M, Majumdar DK 2005, Antibacterial activity of Ocimum sanctum L. fixed oil. Indian J Exp Biol 43:835

27. Singh S, Taneja M, Majumdar DK 2007 Biological activities of Ocimum sanctum L. fixed oil- An overview. Indian J Exp Biol 45,403-412.

28. Singh S, Taneja M, Majumdar DK. 2007 Biological activities of Ocimum sanctum L. fixed oil: An overview. Indian J Exp Biol 45,403-412

29. Singh S, Taneja M, Majumdar DK.,2007 Biological activities of Ocimum sanctum L. fixed oil- An overview. Indian J Exp Biol 45:403-412.

30. Tabassum I, Siddiqui Z N, Rizvi S J. 2010 Effects of Ocimum sanctum and Camellia sinensis on stress induced anxiety and depression in male albino Rattus norvegicus. Indian j pharmacol. 42 (5): 283-288.

31. Uma Devi P, Gonasoundari A, Vrinda B, Srinivasan KK, Unnikrishanan MK. 2000 Radiation protection by the Ocimum sanctum flavonoids orientin and vicenin: Mechanism of action 154(4) 455- 460.

32. Yanpallewar SU, Rai S, Kumar M, Acharya SB 2004 Evaluation of antioxidant and neuroprotective effect of Ocimum sanctum on transient cerebral ischemia and long term cerebral hypoperfusion. PharmacolBiochemBehav 79(1): 155-164.

\section{Source of Support: Nil Conflict of Interest: None Declared}

How to cite this URL: Preeti et al: Tulsi (Ocimum Sanctum Linn.): An Ayurvedic And Contemporary Review. International Ayurvedic Medical Journal \{online\} 2021 \{cited December 2021\} Available from: http://www.iamj.in/posts/images/upload/3134_3138.pdf 